\title{
The Politics of Textualising Recall: Women in Canadian Feminist Histor(iograph)y
}

\author{
Terry Provost
}

Cet article traite de la politique derrière le souvenir collectif de la race. Il argumente que la rubrique " femme » est souvent implicitement catégorisée comme étant blanche dans l'historique féministe canadienne. Ce problème est mis de l'avant à travers un examen des pratiques qui normalisaient les hiérarchies raciales dans le Haut et le Bas Canada.

Whereas women in feminist discourse is intended universally, a myopia exists with its application in Canadian feminist histor(iograph)y. A blindness to race has sustained amnesia around crucial moments in the histories of Native and Black women in eighteenth-century Canada. Such poor-sighted scholarship with its distorted long-lasting (im)prints pose an ethical problem for Canadian feminism. This critique examines some feminist texts which treat women in colonial Canada in a universalist yet c/overtly exclusionary manner. My perspective is not new, merely one that underlines the problem of Whiteness plaguing the political and epistemological models of Canadian feminism.

\section{Women as Canadian and in/visibly white}

Wendy Mitchinson's The Nature of Their Bodies: Women and Their Doctors in Victorian Canada (1991) presents ground-breaking research on Canadian women's gynecological and obstetric issues from the late 1700s and the 1800s. Yet in reading the first few chapters, only White women are discussed. With the thématique of Whiteness not particularised, Mitchinson implicitly centres White Euro-Canadian women as subject/s, relegating Black and First Nations women to the margins. Nootka women's abortion practices and J. Marion Sims' repeated urinary experiments on Black slave women are deferred in abridgements (Mitchinson 235). Readers anticipating the inclusion of women of Colour's gynecological history will remark Mitchinson's taken-for-granted normalisation of Whiteness. 
This absence of White racial contextualisation problematises textual politics, political recall and textual accountability in Canadian feminism, because it memorialises White females as universally important and alternately racialised women as forgettable deviations. Woman in Canadian feminism thus resembles the disguised male-normative subject in White patriarchal rhetoric. Studying Anglo-Canadians' perceptions of race, Marina Valverde asserts that, by the Victorian era, the collective conceptualisation of Whiteness as universal and superior was already well entrenched in Canadian nationalist discourse:

there was ... an implication that the fate of the whole human race hinged on the preservation of the racial health and political dominance of Anglo-Saxons... The slippery term "race" allowed AngloSaxons to think of themselves as both a specific race and as the vanguard of the human race as a whole. The ambiguity of the term. hence allowed white Anglo-Saxon supremacy to be justified without argument or evidence: it was obvious that as Anglo-Saxons progressed or declined, so would the world. (109-10)

Via ambiguity, colonial perceptions of White supremacy established a precedent that has since evolved into discursive modes which in/visibly foreground white subjects.

\section{$\mathrm{Re} /$ Calling the politics of slavery: capitalising on language}

The cover of Canadian Women: A History carries a cameo-like picture of an elegantly dressed White woman whose attire suggests a racialised middleclassness within the frame of Canadian and woman. An emblem of female nationalism, her image ricochets between the title and the visual codes, both articulating and magnifying her identity. Canadian signifies "White" just as equally as does women. Small photo inserts of Native and working women appear at the periphery, the cover revealing the principal organisation of the content. White women's status, benevolence, agency and activism in colonial Canada dominate.

First Nations' intertribal slavery, Black slavery in Nova Scotia and the Underground Railway which linked the United States to Upper Canada surface in certain sections (Prentice et al. 66). Overlooked, though, are European and Euro-Canadian women as slave-owners of both Black and Native women. Describing slavery in Canada as an eighteenth-century colony of France, one passage reads: 
there were poor and abused women in New France, particularly in the urban centres of Quebec, Montreal, and Louisbourg; and there were slaves, both native and black. We read, for example, of a woman slave in Louisbourg who was purchased by a free black so that they could marry. In the annales of the Congrégation de Notre-Dame of Louisbourg we read of a woman and her children who were taken in by the sisters because she had been repeatedly beaten by her husband. In addition, there is the fragmentary record of the slave, MarieJoseph-Angélique who, when threatened with sale, set fire to her owner's house and ran away. (56)

In this quote, "owner" camouflages the gender of Marie-JosephAngélique's master who was, in fact, a White woman (Trudel, éd. abrégée 93). This politically charged term represses the hierarchical class antagonism between women incited through race. Also, the passage is misleading: it conveys that female exploitation was exclusively induced by men, and that women - whether White, Black, Native, bourgeois or working class - always helped each other in a "sister-solidarity" sort of way. But things were not so rosy between women in colonial Canada. Intragender conflict thrived when White women of the bourgeoisie appropriated and exercised the racist practices of colonial patriarchy. Though Marie-JosephAngélique's heroism is well documented, her referencing should raise the question of who could own and exploit (sexually, reproductively or labour-intensively) Native and Black women in Upper and Lower Canada.

Considered two distinct peoples in thinking, culture and attitudes, most anglophones and francophones from Upper and Lower Canada ironically shared American slavocratic beliefs about the order of social privilege that race should be a vertical divider. The descriptives of women of Colour from the late 1700 s to the early 1800 s reflect this vertical division in gender. Native and Black women were excluded from the decorous category of woman. A Dictionary of American English: On Historical Principles (1959) contains the names used for Native and Black women at the turn of the nineteenth century. Squaw or wench, and not woman, were the commonplace substantives. With the combination of dark pigmentation and the female body, colonists came to fear women of colour, who were defined as unclean, evil and hyper-libidinous. In the early 1800s, the fur trade dwindling, these definitions affected highly skilled Native women traders who 
lost their sociopolitical power. They were reduced to sex objects who perpetuated "immorality because of their supposed Indian heritage" (Van Kirk 79). Ron Bourgeault explains that:

As the society was transformed through a policy of domination, Indian women became sexual commodities to be purchased through the exchange of European goods, particularly alcohol, for their services... The very fact that these relationships occurred around the exchange of goods initiated by the European represented prostitution. But it was created through the colonial imposition of relations of domination and exploitation. (99)

Even prepubescent Native girls were bought by White male proprietors. Announcements as the one below were not unusual in colonial Canada:

TO BE SOLD,

A STOUT, healthy Panis Girl, about

12 years of age, has had the small-pox, speaks French and perfectly honest and sober. For further particulars enquire of Melvin, Wills and Burns

(Prévost 230)

The adjectives "stout" and "healthy" seek to convince the buyer of the 12year-old's ability to sustain hard labour. But the blurb mirrors how Panis girls were (re)called and ranked by ethnicity and race in the language of Canadian colonisers.

Printed in The Upper Canada Gazette of 19 August 1795 are two classifieds entitled "A Negro Wench." These appear in the column for monetary exchanges of property, personal belongings, or biens meubles. Marcel Trudel claims that, in the Canadian slavocracies of the 1700s, whether or not baptised, a Pani or Black slave was as good as an animal: "Bien que le Code noir n'ait pas été promulgué au Canada, les esclaves seront ici comme ailleurs des beins meubles et les Canadiens en disposeront comme tels. Biens meubles, c'est-à-dire que les esclaves sont possédés de la même façon que les animaux" (éd. abrégée 57-58).

While the first classified announces the reward for a runaway slave, the fine print prefacing the second indicates that a young Black woman named Chloe was made available by her owner for a rent-to-purchase 
transaction over a three-year period. That in print she possesses no surname immediately places the Black female subject on familiar terms with potential buyers, interpellated as White males. The con/textualising caption "Negro Wench" implicitly constructs Chloe as a servile sex object on auction while the ad silently articulates that she is a nubile 23 , young enough to give (hetero)sexual pleasure, to reproduce and to do "washing, cooking \& c." The juxtaposition of "Negro Wench" and (White) "gentleman" emphasises the efficiency and economy of colonial language in situating subjects by gender, class and race.

With no surname, Chloe's lineage becomes difficult to track, her existence blurred by textual amnesia. In fact, any last names assigned to slaves in colonial Canada were usually those of their previous or current owners, an appellative practice which further affirmed both colonial ownership of women of Colour and dark female bodies as transient capital. Says Trudel: "Malgré leur baptême, beaucoup d'esclaves ont été inscrits dans le registres d'état civil sans aucun nom ni prénom" (éd. abrégée 75). On occasion, slave women were sold mercilessly from proprietor to proprietor, without the slightest regard for their family ties. Trudel explains the erratic, ever-changing situation of one slave woman who was sold repeatedly in Lower Canada: "Marie Bulkley se vend en 1785 à Elias Hall; en 1788 elle appartient à John Lagord qui la cède bientôt à Pierre Joinville au cours d'un échange, puis Joinville en fait don à son gendre Louis Olivier et, enfin, Olivier la vend à Joseph Gent qui la garde comme servante: elle avait eu cinq propriétaires en seulement 12 ans" (L'Esclavage 11).

The solidifying of slavocracies in Upper and Lower Canada was fervently advocated by most inhabitants and government officials alike, by most White women and men alike. Joseph Papineau, the deputy of Montreal East, tried to outlaw slavery in 1800, 1801, and 1803, failing with each attempt (Prévost 231). The demand for slaves was just too popular amongst franco- and anglophone slavocrats in Montreal. A letter written in 1688 by an intendant, thought to be John Baptiste de Lagny, reveals how slavery was to be incorporated into New France's colonial policy:

Les gens de travail et les domestiques sont d'une rareté et d'une cherté si extraordinaire... en Canada, qu'ils ruinent tous ceux qui font quelque entreprise. On croit que le meilleur moyen d'y remédier serait d'avoir des Esclaves Negres [sic]. Le Procureur-Général du Conseil qui est à Paris assure que si Sa Majesté agrée cette proposition, 
quelques uns des principaux habitants en feront acheter aux Isles à l'arrivée des vaisseaux de Guinée et il est lui-même dans cette résolution. (Viger 1-2)

Proposals like Lagny's were designed to introduce a particular labour force into the colony to develop the land. In turn, this would permit Whites to focus on trade and to form a mercantile class (Winks 8). Delegate Jacques Raudot's decree of 1709 shows that slavery in New France was indeed devised to target specific ethnic groups:

in accordance with the wishes of His Majesty, we order that those who have bought or who will hereafter buy any Pani or Negro are to be granted complete ownership of that slave; that these Panis and Negroes are to be forbidden from leaving their Masters; and that a fifty-pound fine is to be levied on anyone who incites slaves to leave their Masters. (5)

Here, Raudot conflates ethnicity with race and class. His language racialises Pani and Negro into a pigmentary hypervisibility that denotes servitude as much as it substantivises Whiteness into a hegemonically normative space of invisibility. The capitalised noun Masters requires no racial adjective whatsoever.

Apart from sentiments of national supremacy, the European/EuroCanadian colonial hegemony considered sex and skin-colour signs of alterity. These signs had to be constantly articulated, ranked and policed, so as not to corrupt the categories of social worth for particular groups. As a matter of course, derogatory colonial naming walled Native and Black females into the definition of exploitable flesh, below the class of woman. Ethnic and racial appellations slid between, or doubled as, adjectives and common nouns which destabilised their subjecthood.

Adopted throughout the colonies of the Americas, the European-governed slave trade cross-culturally cemented the meaning of dark-skinned bodies as easily bought and exchangeable commodities. Certain miscegenated groups also capitalised on the European/Euro-North-American institution of chattel slavery. Ronald Wright notes that, in the early 1800s: "James Vann, a half-blood and the wealthiest man in the Cherokee Nation .... owned a tavern, several ferries, more than fifty black slaves, a distillery, and one of the finest brick houses in what is now Georgia" (208). The 
Iroquois of colonial Canada formed alliances with White colonists and similarly traded Black and Native slaves for profit (Trudel, éd. abrégée 65). White Canadian women literally bought into this practice and shared the master's role as slavocrat.

\section{Sharing the master's role as slavocrat}

Marie-Joseph-Angélique's proprietor at the time of her capture was a widow named Thérèse Decouagne (Trudel, éd. abrégée 92-93). Myriad Canadian women were in Decouagne's position, having become slaveowners via widowhood. As property of male-headed estates, slaves were passed on through wills left behind by husbands for their female spouses (Trudel Dictionnaire 379); and manumission was not a common practice for White women left physically and financially alone in colonial society.

A similar instance of a French-Canadian women owning a Black slave can be seen in a 1784 ad from La Gazette de Québec. Madame Perrault is the mentioned White proprietor who will negotiate the price of the anonymous Black woman auctioned. That the ad generically describes her as "Une Négresse présentment en ville" exoticises her as an object and compels potential buyers to seize the opportunity to purchase this foreign commodity, before she is carted off elsewhere for sale.

Masking intragender racial oppression has come to be a symptom of feminist histor(iograph)ies which promise to examine women's plurality in colonial Canada. A rereading of the unsaid in these discourses is then crucial, to see how absences quietly position and (dis)privilege female subjects in textually reconstructed memory.

\section{Works Cited}

Bourgeault, Ron. "Race, Class and Gender: Colonial Domination of Indian Women." Race, Class, Gender: Bonds and Barriers. Eds. Jesse Vorst et al. Rev ed. Toronto: Garamond, 1991. 88-117.

Mitchinson, Wendy. The Nature of Their Bodies: Women and Their Doctors in Victorian Canada. Toronto: U of Toronto P, 1991.

Prentice, Alison et al. Canadian Women: A History. Toronto: Harcourt Brace Jovanovich, 1988.

Prévost, Robert. Montréal ... La folle entreprise. Montréal: Les éditions internationales Alain Stanké, 1991. 
Raudot, Jacques. "Decree Issued by Intendant, 1709: Decree Issued With Respect to Negroes and the Savages Known as Panis." Rpt. in Some Missing Pages: The Black Community in the History of Québec and Canada. Québec: Ministère de l'éducation, 1995. 5.

Trudel, Marcel. Dictionnaire des esclaves et de leurs propriétaires au Canada français. Montréal: Éditions Hurtubise HMH, 1990.

-. L'Esclavage au Canada français. Édition abrégée. Ottawa: Les Presses Universitaires Laval, 1960.

-. L'Esclavage au Canada français: histoire et conditions de l'esclavage. Ottawa: Les Presses Universitaires Laval, 1960.

Valverde, Mariana. The Age of Light, Soap, and Water: Moral Reform in English Canada, 1885-1925. 1991. Toronto: McClelland and Stewart, 1993.

Van Kirk, Sylvia. "The Role of Native Women in the Fur Trade Society of Western Canada, 1670-1830." Rethinking Canada: The Promise of Women's History. 2nd ed. Eds. Veronica Strong-Boag and Anita Clair Fellman. Toronto: Copp Clark Pitman, 1991. 73-80.

Viger, Jacques. Memoires et documents relatif à l'histoire du Canada. Eds. Jacques Viger et Louis Lafontaine. Montréal: Société historique, 1859.

Winks, Robin. The Blacks in Canada: A History. 2nd ed. Montreal: McGillQueen's UP, 1997.

Wright, Ronald. Stolen Continents: The "New World" Through Indian Eyes. London: Penguin, 1992. 